\title{
Rapid Identification and Isolation of Inhibitors of Rat Lens Aldose Reductase and Antioxidant in Maackia amurensis
}

\author{
Set Byeol Kim, ${ }^{1}$ Seung Hwan Hwang, ${ }^{1}$ Zhiqiang Wang, ${ }^{1}$ \\ Jae Myung Yu, ${ }^{2}$ and Soon Sung Lim ${ }^{1,3}$ \\ ${ }^{1}$ Department of Food Science and Nutrition, Hallym University, 1 Hallymdeahak-gil, Chuncheon 24252, Republic of Korea \\ ${ }^{2}$ Hallym University Kangnam Sacred Heart Hospital, 1, Singil-ro, Yeoungdeungpo-gu, Seoul 07441, Republic of Korea \\ ${ }^{3}$ Institute of Natural Medicine, Hallym University, 1 Hallymdeahak-gil, Chuncheon 24252, Republic of Korea
}

Correspondence should be addressed to Soon Sung Lim; limss@hallym.ac.kr

Received 10 January 2017; Accepted 2 March 2017; Published 6 April 2017

Academic Editor: Zongbao K. Zhao

Copyright (C) 2017 Set Byeol Kim et al. This is an open access article distributed under the Creative Commons Attribution License, which permits unrestricted use, distribution, and reproduction in any medium, provided the original work is properly cited.

Oxidative stress and aldose reductase activity have been implicated in the development of diabetic complications. In this study, the antioxidant and aldose reductase (AR) inhibitory effects of Maackia amurensis (MA) were investigated. The ethyl acetate fraction of the MA extract showed the highest inhibitory activity in antioxidant and rat lens AR (RLAR). To identify and isolate the active components in the ethyl acetate fraction of the MA extract, high-speed countercurrent chromatography and Sephadex LH-20 column chromatography were performed and guided by an offline HPLC-ABTS assay and HPLC microfractionation AR assay. Four antioxidants, namely, piceatannol $\left(\mathrm{IC}_{50}=6.73 \mu \mathrm{M}\right)$, resveratrol $\left(\mathrm{IC}_{50}=11.05 \mu \mathrm{M}\right)$, trans-ferulic acid $\left(\mathrm{IC}_{50}=13.51 \mu \mathrm{M}\right)$, and chlorogenic acid $\left(\mathrm{IC}_{50}=27.23 \mu \mathrm{M}\right)$, and six AR inhibitors, namely, chlorogenic acid $\left(\mathrm{IC}_{50}=4.2 \mu \mathrm{M}\right)$, tectoridin $\left(\mathrm{IC}_{50}=50.4 \mu \mathrm{M}\right)$, genistein $\left(\mathrm{IC}_{50}=57.1 \mu \mathrm{M}\right)$, formononetin $\left(\mathrm{IC}_{50}=69.2 \mu \mathrm{M}\right)$, resveratrol $\left(\mathrm{IC}_{50}=117.6 \mu \mathrm{M}\right)$, and daidzein $\left(\mathrm{IC}_{50}=151.9 \mu \mathrm{M}\right)$, were isolated and identified. The screening results of the offline HPLC-ABTS assay and HPLC microfractionation AR assay matched the activity of isolated compounds. Thus, MA is potentially valuable for antioxidant and AR inhibitor discovery and efficient drug design for the prevention and treatment of diabetic complications.

\section{Introduction}

Hyperglycemia in diabetes mellitus is considered the primary factor for the pathogenesis of long-term diabetic complications, including retinopathy, cataractogenesis, nephropathy, and neuropathy. The polyol pathway is a particularly important mechanism in diabetic complications [1,2]. Aldose reductase (AR, EC.1.1.1.21) is the key rate-limiting enzyme in the polyol pathway and catalyzes the reduction of glucose, in the presence of NADPH, to sorbitol, which can be further oxidized to fructose by sorbitol dehydrogenase in the presence of NADH. During this process, the rate of glucose reduction to sorbitol is faster than that of sorbitol oxidation to fructose. Intracellular accumulation of the osmotically active sorbitol gives rise to osmotic stress and swelling, and thus the membrane permeability changes, promoting cataractogenesis in the lens [3]. Moreover, the changes in the NADPH/ $\mathrm{NADP}^{+}$and NADH/NAD ${ }^{+}$ratios may induce redox imbalance and oxidative stress, further damaging tissues in patients with diabetes [4]. Also, the produced fructose from the polyol pathway is an important contributor to the formation of advanced glycation end products, which cause the dysfunction of vascular wall components [5]. Thus, development of antioxidants and inhibitors of AR to ameliorate oxidative stress and prevent the polyol pathway, respectively, is important for the treatment of diabetic complications. Currently, many potent and active synthetic agents, such as aminoguanidine, metformin, carnosine, and tenilsetam, have been developed as AR inhibitors and antioxidants; however, because of concerns about their adverse effects, there is increasing interest in the development of new AR inhibitors and antioxidants from natural sources [6].

Maackia amurensis (MA) is a deciduous tree distributed widely in the northeast of China as well as in the southern part of the Russian Far East and North Korea. The dried stem bark of this plant has been used as folk medicine for the treatment of cancer, cholecystitis, and arthritis [7]. In previous reports, 
MA has been found to contain various flavones, isoflavones, stilbenes, pterocarpans, dimeric stilbenes, and so forth $[8,9]$.

To identify and isolate bioactive components from natural products, bioassay-guided fractionation is commonly used; however, this old-fashioned approach is time-consuming and labor intensive [10]. Since the advent of high-throughput screening in the early 1990s, offline HPLC-based activity profiling has been proposed and implemented for the effective tracking of bioactive compounds in natural product extracts. Consequently, in recent times, many offline HPLC-based assays have been developed, and many studies have reported successful application of target isolation, that is, offline HPLC-ABTS assay and microfractionation bioassays [11].

To date, however, no data are available on the inhibitory effects of the MA and its constituents on AR. Therefore, as part of our continuing search for new AR inhibitors and antioxidants from natural products, we were to investigate the antioxidant and AR inhibitory effects of the dried stem bark of MA and isolate its active components using high-speed countercurrent chromatography (HSCCC) and Sephadex LH-20 column chromatography guided by an offline HPLCABTS assay and HPLC microfractionation AR assay.

\section{Materials and Methods}

2.1. General Points. ${ }^{1} \mathrm{H}$ and ${ }^{13} \mathrm{C}$ NMR spectra and correlation 2D NMR spectra were obtained from a Bruker Avance DPX 400 (or 600) spectrometer. These spectra were obtained at operating frequencies of $400 \mathrm{MHz}\left({ }^{1} \mathrm{H}\right)$ and 100 (or 150) $\mathrm{MHz}$ $\left({ }^{13} \mathrm{C}\right)$ with $\mathrm{CD}_{3} \mathrm{OD},\left(\mathrm{CD}_{3}\right)_{2} \mathrm{SO},\left(\mathrm{CD}_{3}\right)_{2} \mathrm{CO}$, or $\mathrm{D}_{2} \mathrm{O}$ and TMS used as an internal standard; chemical shifts were reported in $\delta$ values. The molecular mass was measured using the Voyager DE STR matrix assisted laser desorption/ionization time-of-flight (MALDI-TOF) mass spectrometer (MS, Applied Biosystems, Foster City, CA, USA), the low resolution-electronic impact (EI) MS equipped JMS-700 (Tokyo, Japan). Fast atom bombardment (FAB) MS was recorded in the negative form using $m$-nitrobenzyl alcohol as matrix in a JEOL JMSAX 505-WA spectrometer (Tokyo, Japan).

2.2. Reagents and Materials. Nicotinamide adenine dinucleotide phosphate (NADPH), DL-glyceraldehyde dimer, $2,2^{\prime}$ azino-bis(3-ethylbenzothiazline-6-sulfonic acid) diammonium salt (ABTS), 6-hydroxy-2,5,7,8-tetrame-thylchroman2-carboxylic acid (Trolox), aminoguanidine, and quercetin were purchased from Sigma-Aldrich (St. Louis, MO, USA). Ultrapure water used for all solutions was obtained using a Milli-Q laboratory water purification system (Millipore, Bedford, MA, USA) with a resistivity over $18.2 \mathrm{M} \Omega \mathrm{cm}$. All solvents used were purchased from J. T. Baker (Phillipsburg, NJ, USA) and reagents used were purchased from Sigma-Aldrich Co., unless stated otherwise. Plant material (MA, voucher number RIC-2015-7) used in this study was purchased from a local market in Chuncheon, Gangwondo, South Korea.

2.3. Preparation of Extract Sample. The dried bark of MA $(1.2 \mathrm{~kg})$ was refluxed twice with $70 \%$ ethanol extract for $3 \mathrm{~h}$ each. The solvent was evaporated under reduced pressure at $40^{\circ} \mathrm{C}$ to give a $70 \%$ ethanol extract (yield: $7.87 \%$ ). This extract was suspended in distilled water $\left(\mathrm{H}_{2} \mathrm{O}\right)$ and then successively partitioned with $n$-hexane $(n$-Hex), methylene chloride $\left(\mathrm{CH}_{2} \mathrm{Cl}_{2}\right)$, ethyl acetate (EtOAc), $n$-butanol ( $n$ $\mathrm{BuOH}$ ), and $\mathrm{H}_{2} \mathrm{O}$ to yield the $n$-Hex fraction ( $\left.0.60 \mathrm{~g}\right), \mathrm{CH}_{2} \mathrm{Cl}_{2}$ fraction $(5.05 \mathrm{~g})$, EtOAc fraction $(14.76 \mathrm{~g}$ ), and $n-\mathrm{BuOH}$ fraction (9.85 g), as well as the $\mathrm{H}_{2} \mathrm{O}$ fraction (11.05 g). Each extract was dried by rotary evaporation at $40^{\circ} \mathrm{C}$, while the $\mathrm{H}_{2} \mathrm{O}$ fraction was freeze-dried. The EtOAc fraction showed strong inhibitory activities on RLAR and ABTS. Therefore, this fraction was used for ABTS-offline HPLC analysis, HPLC microfractionation AR assay, and isolation.

2.4. HPLC Analysis. HPLC equipment was an Agilent 1200 series instrument (Agilent Technologies, Seoul, Korea) consisting of a vacuum degasser (G1322A), a quaternary pump (G1311A), an autosampler (G1329A), a thermostatted column compartment (TCC, G1316A), and a variable wavelength detector (VWD, G1314D) system. HPLC were achieved using a Gemini column $(150 \times 4.6 \mathrm{~mm}$ i.d., $5 \mu \mathrm{m}$ particle size; Phenomenex). The mobile phase, consisting of $0.1 \%$ aqueous trifluoroacetic acid and acetonitrile, was used at a flow rate of $0.7 \mathrm{~mL} \mathrm{~min}^{-1}$. The gradient elution program was modified as follows for a total of $70 \mathrm{~min}$ : $0-20 \% \mathrm{~B}(0-10 \mathrm{~min}), 20-20 \% \mathrm{~B}$ (10-15 min), 20-25\% B (15-25 min), 25-30\% B (25-35 min), $30-30 \% \mathrm{~B}$ (35-40 min), and 30-100\% B (40-50 min). Injection volume was $10 \mu \mathrm{L}$ at a sample concentration $1 \mathrm{mg} \mathrm{mL}^{-1}$, and the detection wavelength was $254 \mathrm{~nm}$.

\subsection{Isolation and Identification of Activity Compounds}

2.5.1. Distribution of Two-Phase Solvent System. For peaks divided into upper and lower layers, the solvent fraction had the preference with n-hexane-ethyl acetate-methanol-water $(2: 8: 1: 9, \mathrm{v} / \mathrm{v})$. Then, the upper layer was isolated by HSCCC and the lower layer was insulated using Sephadex LH-20.

2.5.2. Preparation of Two-Phase Solvent System and Sample Solution. The two-phase solvent systems were tested to select a suitable solvent system based on the partition coefficient $(K)$. Ten milligrams of the EtOAc fraction from the MA extract was weighed in a $20 \mathrm{~mL}$ test tube and $5 \mathrm{~mL}$ of each phase was added, which preequilibrated a two-phase solvent at room temperature. After the tube was strongly shaken, the solution was checked for a settling time that is closely correlated to the retention of the stationary phase, and then each phase was analyzed by HPLC to obtain the $K$ value of the target compound. The $K$ value was calculated as the peak area in the upper phase divided by the lower layer and then the upper phase was used as the stationary phase, and the lower phase was used as the mobile phase.

\subsubsection{High-Speed Countercurrent Chromatography (HSCCC).} The HSCCC instrument was a model TBE-1000A HSCCC (Tauto Biotechnique Company, Shanghai, China) with three multilayer coil columns (ID of the tubing: $1.8 \mathrm{~mm}$, column volume: $260 \mathrm{~mL}$ ) connected in series and a $50 \mathrm{~mL}$ sample loop. The $\beta$ value $(\beta=r / R$, where $r$ is the distance from the coil to the holder shaft and $R$ is the distance between the holder axis and central axis of the centrifuge) of the multilayer 
coil varies from 0.60 (internal terminal) to 0.80 (external terminal). The revolution speed of the apparatus was regulated at 0-1000 rpm with an electronic speed controller. The HSCCC system was equipped with a Model Hitachi L-6200 intelligent pump (Hitachi, Tokyo, Japan) and an Isolera FLASH purification system (Biotage, Uppsala, Sweden) as UV monitor. The multilayer coil column was first entirely filled with the upper organic phase at a flow rate of $20 \mathrm{~mL} \mathrm{~min}^{-1}$. The lower aqueous phase was pumped into the inlet column as the mobile phase at $5 \mathrm{~mL} \mathrm{~min}^{-1}$, while the apparatus was rotated at $400 \mathrm{rpm}$. The mode for HSCCC separation was "head to tail." After the hydrodynamic equilibrium was established, the EtOAc fraction of the MA extract ( $2 \mathrm{~g}$ in $40 \mathrm{~mL}$ of each phase) was injected into the separation column through the injection valve, and then each peak fraction was collected in $25 \mathrm{~mL}$ tubes while monitored with a UV detector at $254 \mathrm{~nm}$.

2.5.4. Sephadex LH-20 Column Chromatography. A glass column $(90 \mathrm{~cm} \times 3 \mathrm{~cm}$ i.d. $)$ was packed with Sephadex LH-20 gel in $60 \%$ methanol at room temperature. Then, $0.49 \mathrm{~g}$ of the EtOAc fraction of the MA extract in $1.5 \mathrm{~mL}$ of $60 \%$ methanol was loaded to the column and eluted.

2.6. Evaluation of Trolox Equivalent Antioxidant Capacity (TEAC). ABTS radical scavenging activity was evaluated by modifying a previously described protocol $[12,13]$. A $2 \mathrm{mM}$ ABTS stock solution was mixed with $3.5 \mathrm{mM}$ potassium persulfate in distilled water in a bottle wrapped with foil and stored at room temperature for $12 \mathrm{~h}$ until the reaction was complete and the absorbance was stable. To determine scavenging activity, $10 \mu \mathrm{L}$ of sample $\left(3 \mathrm{mg} \mathrm{mL}^{-1}\right.$ in DMSO) was mixed with $290 \mu \mathrm{L}$ ABTS solution in a 96-well microplate and incubated at room temperature for $10 \mathrm{~min}$. Then, the mixture was measured at $750 \mathrm{~nm}$ using a microplate reader and DMSO as a control. Trolox was used as a positive control. The TEAC results are calculated as $\mathrm{IC}_{50}$ values (standard error mean of triplicate experiments) as well as Trolox equivalents (TEAC).

2.7. ABTS-Offline HPLC Assay Analysis. In total, $10 \mu \mathrm{L}$ of the EtOAc fraction from the MA extracts $\left(20 \mathrm{mg} \mathrm{mL}^{-1}\right.$ in methanol) was mixed with $140 \mu \mathrm{L}$ ABTS solution that was prepared one day before. Then, the mixture was incubated at room temperature for $10 \mathrm{~min}$, and then the mixture was filtered through a $0.45 \mu \mathrm{m}$ filter to HPLC analysis. The EtOAc fraction of the MA extract $\left(20 \mathrm{mg} \mathrm{mL}^{-1}\right.$ in methanol) was used as a control. The extents of peak decrease are expressed as a quantitative reduction.

2.8. Assay for Rat Lens AR Inhibitory Activity. Rat lens (RL) homogenate was prepared according to the modified method of Hayman and Kinoshita [14, 15]. RL were removed from the eyes of male Sprague-Dawley rats weighting 250-280 g and were frozen until use. RL were homogenized in $0.10 \mathrm{M}$ sodium phosphate buffer ( $\mathrm{pH}$ 6.2), which was prepared the previous day in sodium phosphate dibasic $\left(\mathrm{Na}_{2} \mathrm{HPO}_{4} \cdot \mathrm{H}_{2} \mathrm{O}\right.$, $0.66 \mathrm{~g})$ and sodium phosphate monobasic $\left(\mathrm{NaH}_{2} \mathrm{PO}_{4} \cdot 2 \mathrm{H}_{2} \mathrm{O}\right.$, $1.27 \mathrm{~g}$ ) in $100 \mathrm{~mL}$ of distilled water. The supernatant was obtained by centrifugation of the homogenate at $10,000 \mathrm{rpm}$ at $4^{\circ} \mathrm{C}$ for $20 \mathrm{~min}$ and was frozen until use. A partially purified enzyme with a specific activity of $6.5 \mathrm{U} \mathrm{mg}^{-1}$ was routinely used to test enzyme inhibition. Each $1 \mathrm{~mL}$ cuvette contained $531 \mu \mathrm{L}$ of $100 \mathrm{mM}$ sodium phosphate buffer $(\mathrm{pH}$ 6.2), $90 \mu \mathrm{L}$ of AR homogenate, $90 \mu \mathrm{L}$ of $1.6 \mathrm{mM} \mathrm{NADPH}, 9 \mu \mathrm{L}$ of the samples dissolved in DMSO, and $90 \mu \mathrm{L}$ of $25 \mathrm{mM}$ of DL-glyceraldehyde as the substrate. The RLAR activity was assayed spectrophotometrically by measuring the decrease in the absorption of NADPH at $340 \mathrm{~nm}$ over a 4 min period [2].

2.9. HPLC Microfractionation of Rat Lens AR. An automated fraction collector (Foxy 200, ISCO, Lincoln, NE, USA) connected to HPLC equipment was used to separate and collect compounds from extracts directly into 96-well plates (Nunc, Roskilde, Denmark), with $0.35 \mathrm{~mL}$ in each well. After collection, 96-well plates were evaporated to dryness using an EZ-2 plus evaporator (Genevac Ltd., Ipswich, UK), and RLAR inhibitory activity was evaluated as described in upper section.

2.10. Statistical Analysis. All data was expressed as mean \pm $\mathrm{SD}$ values from triplicates, analyzed via a one-way analysis of variance (ANOVA) with significant difference between means determined at $p<0.05$, and measured with Duncan's multiple range tests using the Statistical Package for Social Science Research version 19 (SPSS).

\section{Results}

3.1. Determination of Active Target Fraction from the Five Fractionation Extracts of Maackia amurensis. The ethanol extract of MA was fractionated by increasing polarity solvents and was then measured. Antioxidant activity was measured by evaluating the decrease of absorbance at $750 \mathrm{~nm}$ in TEAC assay. The EtOAc fraction had superior activity in ABTS assays with $\mathrm{IC}_{50}$ values of $4.92 \mu \mathrm{g} \mathrm{mL}^{-1}$ and a TEAC value of 1.77 as compared to positive control (Trolox, $\mathrm{IC}_{50}=$ $8.72 \mu \mathrm{g} \mathrm{mL}^{-1}$; TEAC 1.00) (Table 1). The $\mathrm{IC}_{50}$ values of RLAR inhibition, except for the EtOAc fraction from the $70 \%$ ethanol extract, were higher than $100 \mu \mathrm{g} \mathrm{mL}^{-1}$. The EtOAc fraction showed potent inhibition of RLAR with $\mathrm{IC}_{50}$ value of $11.3 \mu \mathrm{g} \mathrm{mL}^{-1}$, as compared to the positive control (quercetin), a well-known AR inhibitor, with an $\mathrm{IC}_{50}$ value of $3.3 \mu \mathrm{g} \mathrm{mL}^{-1}$ (Table 1).

3.2. ABTS ${ }^{+}$Offline HPLC Radical Scavenging Analysis. In order to identify the antioxidants in the EtOAc fraction of the MA extract, an offline HPLC-ABTS assay was developed. The EtOAc fraction of the MA extract spiked with ABTS solution was measured at $254 \mathrm{~nm}$. Accordingly, as shown in Figure $1(\mathrm{a})$, peaks $1,3,5$, and 6 showed peak area reductions, while peak areas of 2, 4, and 7-9 were slightly decreased. Therefore, peaks $1,3,5$, and 6 were considered as potential antioxidants based on the relative peak areas in the HPLC chromatogram.

3.3. Rat Lens AR Inhibition Screening for Using HPLC Microfractionation. According to our results it is necessary to 
TABLE 1: Effects of Maackia amurensis fractions in terms of antioxidation and inhibition of aldose reductase in rat lens.

\begin{tabular}{lccc}
\hline Test sample & Antioxidant & TEAC $^{\mathrm{b}}$ & $\begin{array}{c}\text { RLAR inhibition } \\
\mathrm{IC}_{50}(\mu \mathrm{g} / \mathrm{mL})\end{array}$ \\
\hline Crude & $\mathrm{IC}_{50}(\mu \mathrm{g} / \mathrm{mL})^{\mathrm{a}}$ & 0.72 & $35.6 \pm 3.82$ \\
$n$-Hex fraction & $12.03 \pm 0.02$ & 0.07 & $>100$ \\
$\mathrm{CH}_{2} \mathrm{Cl}_{2}$ fraction & $134.02 \pm 0.78$ & 0.06 & $>100$ \\
EtOAc fraction & $141.13 \pm 0.78$ & 1.77 & $11.3 \pm 4.31$ \\
$n$-BuOH fraction & $4.92 \pm 0.02$ & 0.09 & $>100$ \\
$\mathrm{H}_{2} \mathrm{O}$ fraction & $96.48 \pm 0.45$ & 0.03 & $>100$ \\
Trolox $^{c}$ & $282.62 \pm 0.38$ & 1.00 & - \\
Quercetin $^{\mathrm{d}}$ & $8.72 \pm 0.01$ & - & $3.30 \pm 3.20$ \\
\hline
\end{tabular}

${ }^{\mathrm{a}}$ The $\mathrm{IC}_{50}$ value was defined as the concentration of the $50 \%$ inhibition.

${ }^{\mathrm{b}}$ Trolox equivalent antioxidant capacity.

${ }^{\mathrm{c}}$ Trolox was used as positive control for ABTS assay.

${ }^{\mathrm{d}}$ Quercetin was used as positive control for RLAR inhibitory activity measurement.

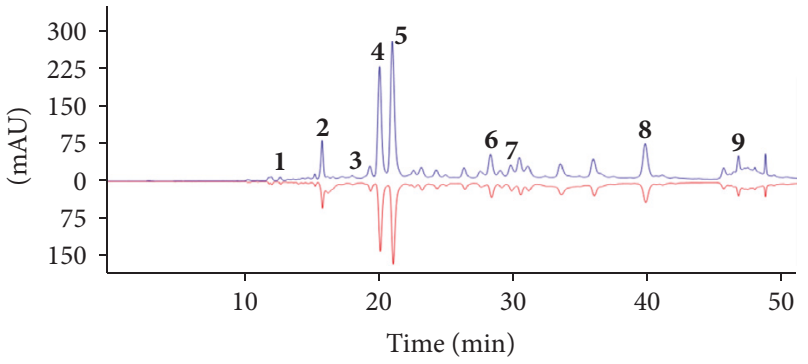

(a)

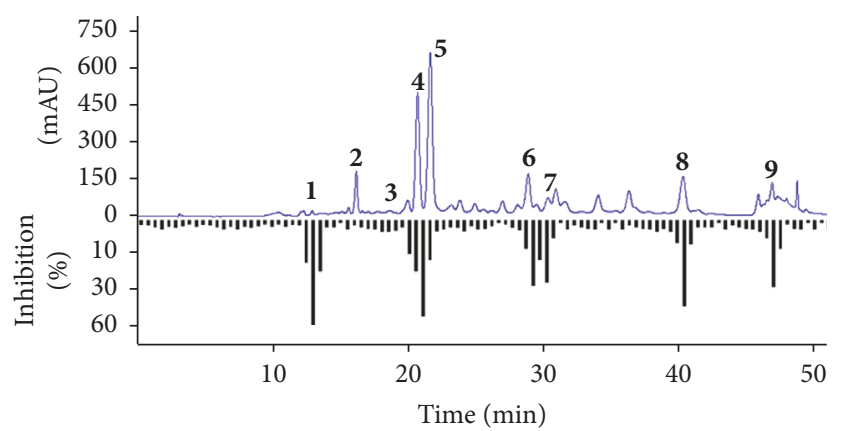

(b)

FIGURE 1: Screening test from the ethyl acetate fraction of Maackia amurensis by offline HPLC. The peak before reaction is the upper line and the peak after reaction is the inverse line in each chromatography. (a) The result of ABTS-offline HPLC for antioxidants. (b) The result of HPLC microfractionation for RLAR inhibition.

confirm the presence of effective RLAR inhibitory compounds in the EtOAc fraction of the MA extract. The EtOAc fraction of the MA extract $(20 \mathrm{mg})$ was microfractioned by HPLC and the fractions were collected in a 96-well plate, of which the RLAR inhibitory activity was then assessed. As shown in Figure 1(b), the RLAR inhibitory activity in the corresponding wells of peak 1 , peak 4 , peak 6 , peak 7 , peak 8 , and peak 9 was $43.2 \%, 41.89 \%, 43.31 \%, 35.14 \%, 45.54 \%$, and $44.11 \%$, respectively.

\subsection{Isolation of Active Target Peaks by HSCCC and Sephadex LH-2O}

3.4.1. Selection of Two-Phase Solvent System and Other Conditions of HSCCC. In order to confirm the inhibitory activities of potent inhibitors, polarity was divided into two layers for easy separation, and then HSCCC and Sephadex chromatography were performed for isolation of each target. In this study, the $K$ value of the EtOAc fraction of the MA extraction compounds was calculated by HPLC. Before HSCCC separation, the EtOAc fraction of MA extract was fractionated by the solvent fraction with n-hexane-ethyl acetate-methanolwater $(2: 8: 1: 9, \mathrm{v} / \mathrm{v})$ to separate active compounds. The EtOAc fraction was divided into two layers (Figure 2), and then five peak values in the upper layer from the EtOAc fraction of the MA extract were determined, as described in Materials and Methods (Table 2). Considering the above three factors, one system was chosen, with n-hexane-ethyl acetate-methanol-water $(2.5: 7.5: 5: 5, \mathrm{v} / \mathrm{v})$ suitable for all five peaks. As shown in Figure 3, we isolated five compounds (5-9) and the isolated compounds evaporated to yield 170.1, 94.6, 8.2, 10.4, and $5.5 \mathrm{mg}$ at 89.7, 91.2, 95.3, 86.8, and 93.1\% purity, respectively, as determined by HPLC.

3.4.2. Isolation of Compounds 1-4 by Using Sephadex LH20. The lower layer, including peaks 1-4 from the solvent fractioning, was separated by a Sephadex LH-20 column eluted with $60 \%$ methanol because the $K$ values of each component are overlapped. Four compounds were observed and compound 2 was purified by recycle-HPLC to improve its purity. In two experiments, the four compounds (1-4) were evaporated and measured, and the weights were 3.2, 5.0, 3.8, and $44.5 \mathrm{mg}$ at $92.3,98.1,89.7$, and $95.8 \%$ purity, respectively, as determined by HPLC (Figure 4). All nine compounds were identified by comparing ${ }^{1} \mathrm{H}$ and ${ }^{13} \mathrm{C}-\mathrm{NMR}$, EI-MS, and $\mathrm{UV}$ to previously reported data [16-25]. The compounds were chlorogenic acid (1), formononetin-7-O- $\beta$-D-glucosyl [1-6] glucoside (2), trans-ferulic acid (3), tectoridin (4), piceatannol (5), resveratrol (6), daidzein (7), genistein (8), and formononetin (9) (Figure 5). 
TABLE 2: The partition coefficients $(K)$ of the target compounds in several solvent systems.

\begin{tabular}{|c|c|c|c|c|c|c|c|}
\hline \multirow{2}{*}{ Types of solvent system } & \multirow{2}{*}{ Ratio (v/v) } & \multirow{2}{*}{ Settling time (s) } & \multicolumn{5}{|c|}{$K$ values } \\
\hline & & & Peak 5 & Peak 6 & Peak 7 & Peak 8 & Peak 9 \\
\hline n-Heptane-ethyl acetate-methanol-water & $1: 6: 1: 6$ & 9 & - & 9.56 & - & - & - \\
\hline$n$-Hexane-ethyl acetate-methanol-water & $1: 3: 1: 3$ & 13 & - & - & - & 35.34 & - \\
\hline n-Hexane-ethyl acetate-methanol-water & $3: 7: 4.5: 5.5$ & 25 & 0.34 & 0.59 & - & 2.52 & 0.40 \\
\hline n-Hexane-ethyl acetate-methanol-water & $2.5: 7.5: 5: 5$ & 23 & 0.37 & 0.57 & 1.01 & 2.04 & 0.33 \\
\hline$n$-Hexane-ethyl acetate-methanol-water & $4: 6: 3.5: 5.5$ & 30 & 0.37 & 0.90 & 0.69 & 3.73 & 0.39 \\
\hline$n$-Hexane-ethyl acetate-methanol-water & $4: 6: 2.5: 7.5$ & 28 & 3.91 & 4.62 & - & 15.01 & 3.39 \\
\hline
\end{tabular}

Peak 5, piceatannol; peak 6, resveratrol; peak 7, daidzein; peak 8, genistein; peak 9, formononetin.

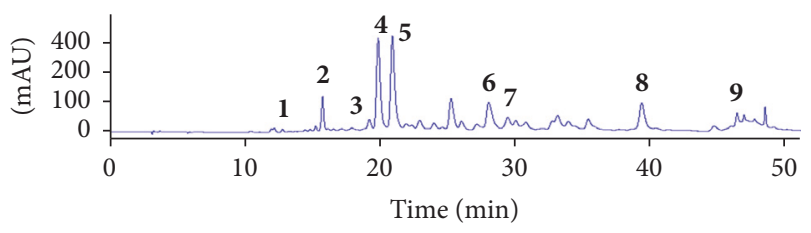

(a)

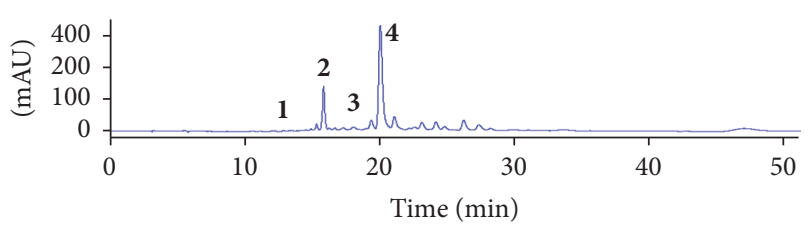

(b)

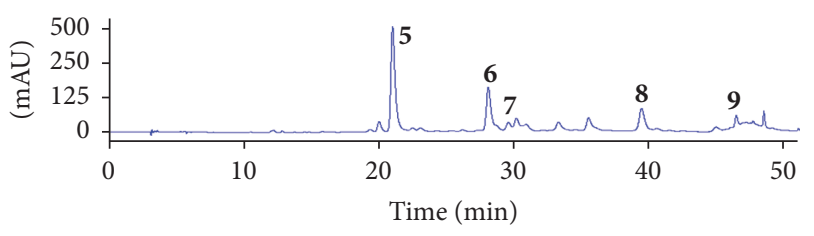

(c)

Figure 2: HPLC analysis of ethyl acetate fractions from Maackia amurensis by an $n$-hexane-EtOAc-methanol-water $(2: 8: 1: 9, \mathrm{v} / \mathrm{v})$ solvent system divided into two layers. (a) EtOAc fraction of Maackia amurensis. (b) The lower layer is included in methanolwater solution. (c) The upper layer is included in $n$-hexane-EtOAc solution.

Compound 1. MALDI-TOF MS $m / z 377.1275[\mathrm{M}+\mathrm{Na}]^{+}, 191$ $[\mathrm{M} \text {-quinic acid-H }]^{-}, 179[\mathrm{M} \text {-caffeic acid-H }]^{-}$. UV (MeCN, $\left.\lambda_{\max } \mathrm{nm}\right) 298,346 .{ }^{1} \mathrm{H}-\mathrm{NMR}(400 \mathrm{MHz}, \mathrm{MeOD}): \delta 7.58(1 \mathrm{H}$, d, $J=15.5 \mathrm{~Hz}, \mathrm{H}-7), 7.06\left(1 \mathrm{H}, \mathrm{d}, J=2.0 \mathrm{~Hz}, \mathrm{H}-2^{\prime}\right), 6.97(1 \mathrm{H}$, dd, $J=8.0$ and $\left.2.0 \mathrm{~Hz}, \mathrm{H}-6^{\prime}\right), 6.79(1 \mathrm{H}, \mathrm{d}, J=8.0 \mathrm{~Hz}, \mathrm{H}-$ $\left.5^{\prime}\right), 6.28\left(1 \mathrm{H}, \mathrm{d}, J=16.0 \mathrm{~Hz}, \mathrm{H}-8^{\prime}\right), 2.05-3.72(2 \mathrm{H}, \mathrm{m}, \mathrm{H}-2,3$ and 6). ${ }^{13} \mathrm{C}-\mathrm{NMR}(400 \mathrm{MHz}, \mathrm{MeOD}): \delta 175.8(\mathrm{C}-7), 167.3(\mathrm{C}-$ $\left.9^{\prime}\right), 147.2\left(\mathrm{C}-4^{\prime}\right), 145.7\left(\mathrm{C}-7^{\prime}\right), 145.4\left(\mathrm{C}-3^{\prime}\right), 126.4\left(\mathrm{C}-1^{\prime}\right), 122.5$ $\left(\mathrm{C}-6^{\prime}\right), 115.1\left(\mathrm{C}-8^{\prime}\right), 114.1\left(\mathrm{C}-5^{\prime}\right), 113.8\left(\mathrm{C}-2^{\prime}\right), 74.9(\mathrm{C}-1), 72.3$ (C-3), 70.1 (C-4), 69.8 (C-5), 36.8 (C-2), 37.6 (C-6).

Compound 2. FAB-MS $m / z 609[\mathrm{M}+\mathrm{H}]^{+}$. UV $\left(\mathrm{MeCN}, \lambda_{\max }\right.$ nm) 263, 330. ${ }^{1} \mathrm{H}-\mathrm{NMR}(400 \mathrm{MHz}, \mathrm{MeOD}): \delta 8.68(1 \mathrm{H}, \mathrm{s}, \mathrm{H}-$ 2), 8.02 (1H, d, $J=7.5 \mathrm{~Hz}, \mathrm{H}-5), 7.39\left(2 \mathrm{H}, \mathrm{d}, J=8.5 \mathrm{~Hz}, \mathrm{H}-2^{\prime}\right.$ and $\left.6^{\prime}\right), 6.98(1 \mathrm{H}, \mathrm{dd}, J=7.5$ and $1.5 \mathrm{~Hz}, \mathrm{H}-6), 7.18(1 \mathrm{H}, \mathrm{d}$,

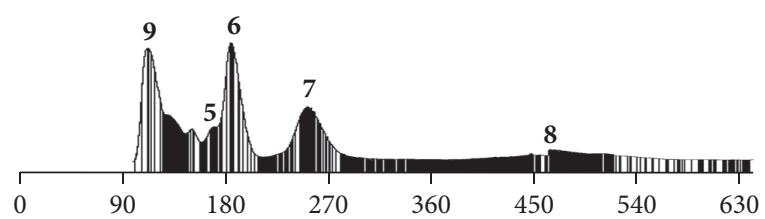

(a)

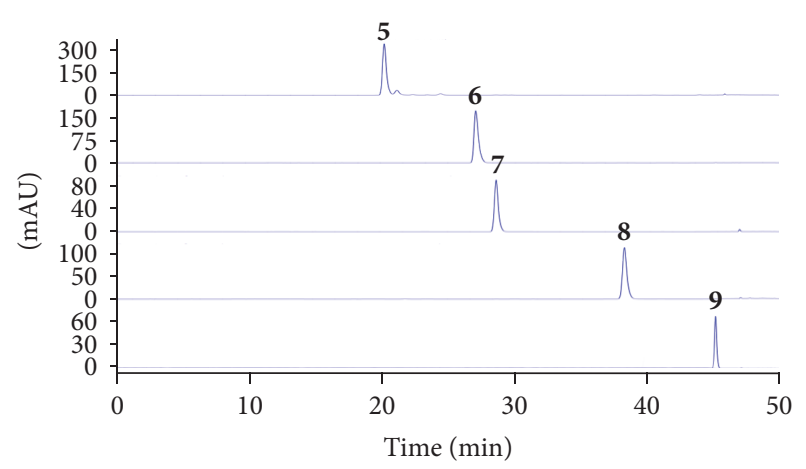

(b)

FIGURE 3: HSCCC separation of active compounds from an ethyl acetate fraction of Maackia amurensis. (a) The upper layer from an ethyl acetate fraction of Maackia amurensis from an HSCCC separation solvent system: $n$-hexane-EtOAc-methanolwater $(2.5: 7.5: 5: 5, \mathrm{v} / \mathrm{v})$; flow rate, $4.0 \mathrm{~mL} / \mathrm{min}$; revolution speed, $500 \mathrm{rpm}$; sample size, $2.0 \mathrm{~g}$; injection volume, $40 \mathrm{~mL}$; detection wavelength, $254 \mathrm{~nm}$. (b) HPLC analysis of isolated compounds by an HSCCC system; peak 5, piceatannol; peak 6, resveratrol; peak 7, daidzein; peak 8 , genistein; peak 9 , formononetin.

$J=3.0 \mathrm{~Hz}, \mathrm{H}-8), 6.85\left(2 \mathrm{H}, \mathrm{d}, J=8.7 \mathrm{~Hz}, \mathrm{H}-3^{\prime}\right.$ and $\left.5^{\prime}\right), 3.83$ $\left(3 \mathrm{H}, \mathrm{s}, \mathrm{H}-4^{\prime}-\mathrm{OCH}_{3}\right), 3.43-5.21(14 \mathrm{H}, \mathrm{m}, \mathrm{O}-\beta$-glucosyl [1-6] glc). ${ }^{13} \mathrm{C}-\mathrm{NMR}(400 \mathrm{MHz}, \mathrm{MeOD}): \delta 175.3$ (C-4), $161.4(\mathrm{C}-7)$, $159.8\left(\mathrm{C}-4^{\prime}\right), 157.8$ (C-8a), 153.2 (C-2), $130.1\left(\mathrm{C}-2^{\prime}\right), 130.1$ (C$\left.6^{\prime}\right), 127.4(\mathrm{C}-5), 124.8\left(\mathrm{C}-1^{\prime}\right), 123.5(\mathrm{C}-3), 117.2(\mathrm{C}-4 \mathrm{a}), 115.7$ (C6), $114.2\left(\mathrm{C}-3^{\prime}\right), 114.2\left(\mathrm{C}-5^{\prime}\right), 109.2\left(\mathrm{Glc}^{\prime \prime}{ }^{\prime \prime}\right), 102.0(\mathrm{C}-8), 100.5$ $\left(\right.$ Glc-1 $\left.{ }^{\prime}\right), 78.1\left(\right.$ Glc-5 $\left.^{\prime \prime}\right), 76.8\left(\mathrm{Glc}^{\prime} 3^{\prime}\right), 76.8\left(\mathrm{Glc}-5^{\prime}\right), 76.1$ (Glc$\left.3^{\prime \prime}\right), 73.8\left(\mathrm{Glc}^{\prime \prime}\right), 73.4\left(\mathrm{Glc}^{\prime}{ }^{\prime}\right), 71.5\left(\mathrm{Glc}^{\prime \prime}{ }^{\prime \prime}\right), 70.3$ (Glc- $\left.{ }^{\prime}\right)$, $68.6\left(\mathrm{Glc}^{\prime} 6^{\prime}\right), 61.5\left(\mathrm{Glc}-6^{\prime \prime}\right), 55.8\left(4^{\prime}-\mathrm{OCH}_{3}\right)$.

Compound 3. EI-MS $m / z 194[\mathrm{M}]^{+}$. UV (MeCN, $\left.\lambda_{\max } \mathrm{nm}\right)$ 239, 323. ${ }^{1} \mathrm{H}-\mathrm{NMR}(400 \mathrm{MHz}, \mathrm{MeOD}): \delta 7.45(1 \mathrm{H}, \mathrm{d}, J=$ $15.7 \mathrm{~Hz}, \mathrm{H}-7), 7.16(1 \mathrm{H}, \mathrm{d}, J=2.1 \mathrm{~Hz}, \mathrm{H}-2), 6.79(1 \mathrm{H}, \mathrm{d}$, $J=8.3$ and $2.1 \mathrm{~Hz}, \mathrm{H}-6), 6.67(1 \mathrm{H}, \mathrm{d}, J=8.5 \mathrm{~Hz}, \mathrm{H}-5)$, 


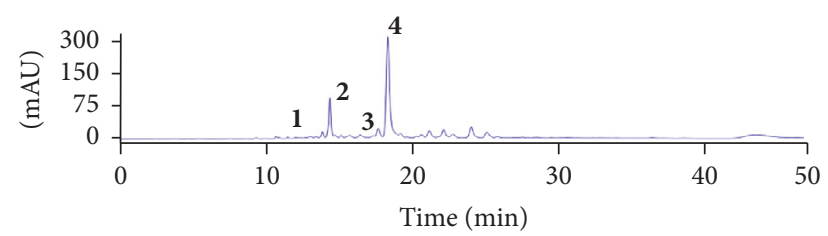

(a)

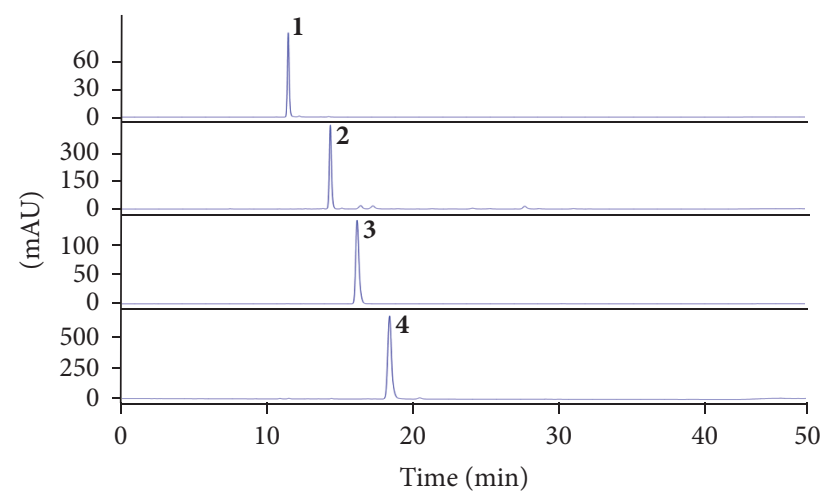

(b)

FIgURE 4: The lower layer of ethyl acetate soluble fraction from Maackia amurensis was isolated with Sephadex LH-20 and isolated compounds were monitored by HPLC analysis at $254 \mathrm{~nm}$. (a) The lower layer of EtOAc fraction from $M$. amurensis. (b) Isolated compounds; peak 1, chlorogenic acid; peak 2, formononetin-7-O$\beta$-D-glucosyl [1-6] glucoside; peak 3, trans-ferulic acid; peak 4, tectoridin.

$6.33(1 \mathrm{H}, \mathrm{d}, J=15.1 \mathrm{~Hz}, \mathrm{H}-8), 3.83\left(3 \mathrm{H}, \mathrm{s}, \mathrm{H}-3-\mathrm{OCH}_{3}\right) .{ }^{13} \mathrm{C}-$ NMR (400 MHz, MeOD): $\delta 171.4$ (C-9), 149.1 (C-3), 147.9 (C4), 146.8 (C-7), 127.6 (C-1), 122.9 (C-6), 119.1 (C-2), 116.4 (C-5), $114.8(\mathrm{C}-8), 56.1\left(3-\mathrm{OCH}_{3}\right)$.

Compound 4. FAB-MS $m / z 463[\mathrm{M}+\mathrm{H}]^{+}$. UV $\left(\mathrm{MeCN}, \lambda_{\max }\right.$ nm) 263, 330. ${ }^{1} \mathrm{H}-\mathrm{NMR}(400 \mathrm{MHz}, \mathrm{MeOD}): \delta 8.15(1 \mathrm{H}, \mathrm{s}, \mathrm{H}-$ 2), $7.39\left(2 \mathrm{H}, \mathrm{d}, J=8.7 \mathrm{~Hz}, \mathrm{H}-2^{\prime}\right.$ and $\left.6^{\prime}\right), 6.88(1 \mathrm{H}, \mathrm{s}, \mathrm{H}-8), 6.85$ $\left(2 \mathrm{H}, \mathrm{d}, J=8.7 \mathrm{~Hz}, \mathrm{H}-3^{\prime}\right.$ and $\left.5^{\prime}\right), 5.06\left(1 \mathrm{H}, \mathrm{s}, \mathrm{Glc}-1^{\prime \prime}\right), 3.76(1 \mathrm{H}$, s, H-6-OCH $\mathrm{OCH}_{3}$, 3.51-4.02 (5H, m, Glc-2", $3^{\prime \prime}, 4^{\prime \prime}, 5^{\prime \prime}$ and $\left.6^{\prime \prime}\right)$. ${ }^{13} \mathrm{C}-\mathrm{NMR}$ (400 MHz, MeOD): $\delta 181.2$ (C-4), 157.9 (C-4' ), 157.1 (C-9), 155.2 (C-2), 153.4 (C-5), 152.9 (C-7), 132.9 (C-6), 130.6 $\left(\mathrm{C}-2^{\prime}\right), 130.6\left(\mathrm{C}-6^{\prime}\right), 122.5(\mathrm{C}-3), 121.5\left(\mathrm{C}-1^{\prime}\right), 115.6\left(\mathrm{C}-3^{\prime}\right), 115.6$ $\left(\mathrm{C}-5^{\prime}\right), 106.9$ (C-10), 100.6 (Glc-1 $\left.^{\prime \prime}\right), 94.5$ (C-8), 77.7 (Glc-5 $\left.{ }^{\prime \prime}\right)$, $77.2\left(\right.$ Glc- $\left.^{\prime \prime}\right), 73.6\left(\right.$ Glc- $\left.^{\prime \prime}\right), 70.1\left(\right.$ Glc $\left.^{\prime \prime}{ }^{\prime \prime}\right), 61.0\left(\right.$ Glc- $\left.^{\prime \prime}\right), 60.8$ $\left(\mathrm{C}-6-\mathrm{OCH}_{3}\right)$.

Compound 5. EI-MS $m / z 243[\mathrm{M}-\mathrm{H}]^{-}$. UV (MeCN, $\lambda_{\max }$ nm) 317. ${ }^{1} \mathrm{H}-\mathrm{NMR}(400 \mathrm{MHz}, \mathrm{MeOD}): \delta 6.96(1 \mathrm{H}, \mathrm{d}, J=$ $1.8 \mathrm{~Hz}, \mathrm{H}-2), 6.88(1 \mathrm{H}, \mathrm{d}, J=16.4 \mathrm{~Hz}, \mathrm{H}$-olefinic $), 6.82(1 \mathrm{H}$, $\mathrm{dd}, J=8.1$ and $2.0 \mathrm{~Hz}, \mathrm{H}-6), 6.74(1 \mathrm{H}, \mathrm{d}, J=16.4 \mathrm{~Hz}, \mathrm{H}-$ olefinic), $6.73(1 \mathrm{H}, \mathrm{d}, J=8.0 \mathrm{~Hz}, \mathrm{H}-5), 6.42(2 \mathrm{H}, \mathrm{d}, J=$ $1.9 \mathrm{~Hz}, \mathrm{H}-2^{\prime}$ and $\left.6^{\prime}\right), 6.14\left(1 \mathrm{H}, \mathrm{t}, J=2.1 \mathrm{~Hz}, \mathrm{H}-4^{\prime}\right) .{ }^{13} \mathrm{C}-$ NMR (400 MHz, MeOD): $\delta 158.7$ (C-3'), 158.7 (C-5'), 145.3 (C-3), 145.3 (C-4), 141.2 (C-1'), 130.1 (C-1), 127.4 (olefinic), 126.4 (olefinic), 119.6 (C-6), 115.8 (C-5), 115.1 (C-2), 104.9 (C$\left.2^{\prime}\right), 104.9\left(\mathrm{C}-6^{\prime}\right), 102.1\left(\mathrm{C}-4^{\prime}\right)$.
Compound 6. EI-MS $m / z 227[\mathrm{M}-\mathrm{H}]^{-}$. UV (MeCN, $\lambda_{\max }$ $\mathrm{nm}) 340 .{ }^{1} \mathrm{H}-\mathrm{NMR}(400 \mathrm{MHz}, \mathrm{MeOD}): \delta 7.35(2 \mathrm{H}, \mathrm{d}, J=$ $8.8 \mathrm{~Hz}, \mathrm{H}-2$ and 6), 6.95 (1H, d, $J=16.4 \mathrm{~Hz}, \mathrm{H}$-olefinic), 6.87 $(1 \mathrm{H}, \mathrm{d}, J=16.4 \mathrm{~Hz}, \mathrm{H}$-olefinic $), 6.75(2 \mathrm{H}, \mathrm{d}, J=8.8 \mathrm{~Hz}, \mathrm{H}-$ 3 and 5), $6.38\left(2 \mathrm{H}, \mathrm{d}, J=2.2 \mathrm{~Hz}, \mathrm{H}-2^{\prime}\right.$ and $\left.6^{\prime}\right), 6.27(1 \mathrm{H}, \mathrm{t}$, $\left.J=2.2 \mathrm{~Hz}, \mathrm{H}-4^{\prime}\right) .{ }^{13} \mathrm{C}-\mathrm{NMR}(400 \mathrm{MHz}, \mathrm{MeOD}): \delta 158.2(\mathrm{C}-$

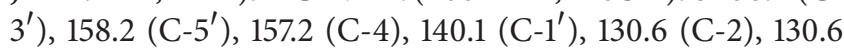
(C-6), 129.1 (C-1), 128.0 (olefinic), 127.4 (olefinic), 115.8 (C-3), 115.8 (C-5), $104.6\left(\mathrm{C}-2^{\prime}\right), 104.6\left(\mathrm{C}-6^{\prime}\right), 101.7\left(\mathrm{C}-4^{\prime}\right)$.

Compound 7. EI-MS $m / z 254[\mathrm{M}]^{-}$. UV (MeCN, $\left.\lambda_{\max } \mathrm{nm}\right)$ 250, 303. ${ }^{1} \mathrm{H}-\mathrm{NMR}$ (400 MHz, MeOD): $\delta 8.25$ (1H, s, H-2), $7.96(1 \mathrm{H}, \mathrm{d}, J=9.1 \mathrm{~Hz}, \mathrm{H}-5), 7.36\left(2 \mathrm{H}, \mathrm{d}, J=8.9 \mathrm{~Hz}, \mathrm{H}-2^{\prime}\right.$ and $\left.6^{\prime}\right), 6.90(1 \mathrm{H}, \mathrm{dd}, J=9.1$ and $2.2 \mathrm{~Hz}, \mathrm{H}-6), 6.80(1 \mathrm{H}, \mathrm{H}-8, \mathrm{~d}$, $J=2.0 \mathrm{~Hz}), 6.72\left(2 \mathrm{H}, \mathrm{d}, J=8.9 \mathrm{~Hz}, \mathrm{H}-3^{\prime}\right.$ and $\left.5^{\prime}\right) .{ }^{13} \mathrm{C}-\mathrm{NMR}$ (400 MHz, MeOD): $\delta 178.6$ (C-4), 165.0 (C-7), 158.6 (C-2), 158.6 (C-9), $157.7\left(\mathrm{C}-4^{\prime}\right), 138.2$ (C-8), $132.1(\mathrm{C}-6), 130.2\left(\mathrm{C}-2^{\prime}\right)$, 130.2 (C-6 $\left.{ }^{\prime}\right), 125.1\left(\mathrm{C}-1^{\prime}\right), 123.5(\mathrm{C}-3), 118.2(\mathrm{C}-10), 107.0\left(\mathrm{C}-3^{\prime}\right)$, $107.0\left(\mathrm{C}-5^{\prime}\right), 103.5(\mathrm{C}-5)$.

Compound 8. EI-MS $m / z 270[\mathrm{M}]^{+}$. UV (MeCN, $\left.\lambda_{\max } \mathrm{nm}\right)$ 261, 328. ${ }^{1} \mathrm{H}-\mathrm{NMR}$ (400 MHz, MeOD): $\delta 8.04$ (1H, s, H-2), $7.36\left(2 \mathrm{H}, \mathrm{d}, J=8.7 \mathrm{~Hz}, \mathrm{H}-2^{\prime}\right.$ and $\left.6^{\prime}\right), 6.84(2 \mathrm{H}, \mathrm{d}, J=8.4 \mathrm{~Hz}$, $\mathrm{H}-3^{\prime}$ and $\left.5^{\prime}\right), 6.33(1 \mathrm{H}, \mathrm{d}, J=2.1 \mathrm{~Hz}, \mathrm{H}-8), 6.20(1 \mathrm{H}, \mathrm{d}$, $J=2.2 \mathrm{~Hz}, \mathrm{H}-6) .{ }^{13} \mathrm{C}-\mathrm{NMR}(400 \mathrm{MHz}, \mathrm{MeOD}): \delta 180.7(\mathrm{C}-$ 4), 166.4 (C-7), 161.8 (C-5), 157.8 (C-9), 157.7 (C-4' $), 153.2$ (C-

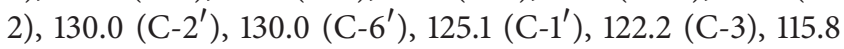
$\left(\mathrm{C}-3^{\prime}\right), 115.8\left({\mathrm{C}-5^{\prime}}^{\prime}\right), 105.5$ (C-10), 98.5 (C-6), 94.1 (C-8).

Compound 9. EI-MS $m / z 269[\mathrm{M}+\mathrm{H}]^{+}$. UV (MeCN, $\lambda_{\max }$ nm) $253,300 .{ }^{1} \mathrm{H}-\mathrm{NMR}(400 \mathrm{MHz}, \mathrm{MeOD}): \delta 8.16(1 \mathrm{H}, \mathrm{s}, \mathrm{H}-$ 2), $7.96(1 \mathrm{H}, \mathrm{d}, J=8.7 \mathrm{~Hz}, \mathrm{H}-5), 7.46\left(2 \mathrm{H}, \mathrm{d}, J=8.7 \mathrm{~Hz}, \mathrm{H}-2^{\prime}\right.$ and $\left.6^{\prime}\right), 6.98\left(2 \mathrm{H}, \mathrm{d}, J=8.7 \mathrm{~Hz}, \mathrm{H}-3^{\prime}\right.$ and $\left.5^{\prime}\right), 6.93(1 \mathrm{H}, \mathrm{dd}$, $J=8.8$ and $2.1 \mathrm{~Hz}, \mathrm{H}-6), 6.85(1 \mathrm{H}, \mathrm{d}, J=1.8 \mathrm{~Hz}, \mathrm{H}-8) .{ }^{13} \mathrm{C}-$ NMR (400 MHz, MeOD): $\delta 175.3$ (C-4), 160.8 (C-7), $158.6(\mathrm{C}-$ 9), $157.8\left({\mathrm{C}-4^{\prime}}^{\prime}\right), 153.1(\mathrm{C}-2), 131.4\left(\mathrm{C}-2^{\prime}\right), 131.4\left(\mathrm{C}-6^{\prime}\right), 128.1(\mathrm{C}-$ 5), 125.3 (C-3), 125.2 (C-10), $125.1\left(\mathrm{C}-1^{\prime}\right), 115.0$ (C-6), $114.5(\mathrm{C}-$ $\left.3^{\prime}\right), 114.5\left(\mathrm{C}-5^{\prime}\right), 103.4(\mathrm{C}-8), 55.7\left(\mathrm{C}-4^{\prime}-\mathrm{OCH}_{3}\right)$.

\subsection{Activity Assessment of Isolated Compounds}

3.5.1. Antioxidant Effect of Isolated Compounds. The antioxidant activities of compounds were confirmed by ABTS assay (Table 3). Compounds 5 and 6 had stilbene structures and showed potent inhibitory activity, with $\mathrm{IC}_{50}$ values of $6.73 \mu \mathrm{M}$ and $11.05 \mu \mathrm{M}$ as compared to the positive control, Trolox, with an $\mathrm{IC}_{50}$ value of $16.83 \mu \mathrm{M}$. Compounds 1 and 3 , which were phenols, also had higher $\mathrm{IC}_{50}$ values compared to Trolox (27.23 $\mu \mathrm{M}$ and $13.51 \mu \mathrm{M}$, resp.). Other isolated compounds, 2,4 , and 7-9, were flavonoids that did not have antioxidant activity.

3.5.2. Rat Lens AR Inhibitory Activity of the Isolated Compounds. The ARI were performed to confirm the activities of compounds (Table 3). Compound 1 showed the maximum inhibitory activity of $\mathrm{AR}$ with an $\mathrm{IC}_{50}$ value of $4.2 \mu \mathrm{M}$ as compared to the positive control, quercetin, with an $\mathrm{IC}_{50}$ value of $10.1 \mu \mathrm{M}$. Compound 4 exhibited the second highest 
<smiles>[R]C(=O)/C=C/c1ccc(O)c([R10])c1</smiles>

\begin{tabular}{lccc}
\hline Number & Name & $\mathrm{R}_{1}$ & $\mathrm{R}_{2}$ \\
\hline $\mathbf{1}$ & Chlorogenic acid & Quinic acid & $\mathrm{H}$ \\
$\mathbf{3}$ & trans-Ferulic acid & $\mathrm{OH}$ & $\mathrm{CH}_{3}$ \\
\hline
\end{tabular}<smiles>[R7]c1cc(/C=C/c2cc(O)cc(O)c2)ccc1O</smiles>

\begin{tabular}{lcc}
\hline Number & Name & $\mathrm{R}_{1}$ \\
\hline $\mathbf{5}$ & Piceatannol & $\mathrm{OH}$ \\
$\mathbf{6}$ & Resveratrol & $\mathrm{H}$ \\
\hline
\end{tabular}<smiles>[R20]c1ccc(-c2coc3cc([R20])c([R4])c([R3])c3c2=O)cc1</smiles>

\begin{tabular}{|c|c|c|c|c|c|}
\hline Number & Name & $\mathrm{R}_{1}$ & $\mathrm{R}_{2}$ & $\mathrm{R}_{3}$ & $\mathrm{R}_{4}$ \\
\hline 2 & Formononetin-7-O- $\beta$-D-glucosy1 [1-6] glucoside & $-\beta$-D-Glucosy1 [1-6] glucose & $\mathrm{OH}$ & $\mathrm{H}$ & $\mathrm{CH}_{3}$ \\
\hline 4 & Tectoridin & $-\beta$-D-Glucose & $\mathrm{OCH}_{3}$ & $\mathrm{OH}$ & $\mathrm{H}$ \\
\hline 7 & Daidzein & $\mathrm{H}$ & $\mathrm{H}$ & $\mathrm{H}$ & $\mathrm{H}$ \\
\hline 8 & Genistein & $\mathrm{H}$ & $\mathrm{H}$ & $\mathrm{OH}$ & $\mathrm{H}$ \\
\hline 9 & Formononetin & $\mathrm{H}$ & $\mathrm{H}$ & $\mathrm{H}$ & $\mathrm{CH}_{3}$ \\
\hline
\end{tabular}

FIGURE 5: Chemical structure of compounds identified from the ethyl acetate fraction of Maackia amurensis.

activity, with an $\mathrm{IC}_{50}$ value of $50.4 \mu \mathrm{M}$, and $8,9,6$, and 7 showed decreasing antioxidant activity, as shown in Table 3. Other isolated compounds, 2, 3, and 5, were flavonoids that did not have RLAR activity.

\section{Discussion}

Diabetic complications including cataracts, neuropathy, nephropathy, and retinopathy caused by several mechanisms can be retarded by inhibiting $\mathrm{AR}$ in the polyol pathway and decreasing oxidative stress [3]. In the present study, we investigated the inhibitory effect of MA on RLAR and ABTS assay and could know that it would be useful for treatment of diabetic complications. To rapidly identify screening of active compounds from MA, we used offline HPLC-ABTS assay and microfractionation AR assay using HPLC. The offline HPLCABTS assay could identify antioxidants from complex mixtures without isolation process. The peak area of efficacious compounds will decrease in chromatography after adding ABTS; however, other compound peak areas without antioxidant activity are not changed [10]. Microfractionation using HPLC also plays an important role in the search for active compounds from plants, providing rapid access to information concerning both the activity and localization of the activity in complex plant matrices [11]. As shown in Table 3, antioxidant and AR inhibitory activities of compounds well matched the quantitative results of the ABTS-offline HPLC assay and microfractionation using HPLC, respectively. We believe that ABTS-offline HPLC assay and microfractionation using HPLC can be very efficient and fast for screening active compounds from complex mixtures, particularly nature products.

Active components from MA extract were separated by HSCCC, which was widely applied as a convenient and efficient technique. For HSCCC separation, the solvent system is the most important step. Commonly, three factors are 
TABLE 3: Antioxidant and aldose reductase inhibitory effects in rat lens of nine compounds isolated from the ethyl acetate fraction of Maackia amurensis.

\begin{tabular}{|c|c|c|c|c|}
\hline \multirow{2}{*}{ Isolated compounds } & \multicolumn{2}{|l|}{ Antioxidant } & \multicolumn{2}{|c|}{ RLAR inhibition } \\
\hline & Quantitative reduction $(\%)^{\mathrm{a}}$ & $\mathrm{IC}_{50}(\mu \mathrm{M})^{\mathrm{b}}$ & Inhibition $(\%)^{c}$ & $\mathrm{IC}_{50}(\mu \mathrm{M})$ \\
\hline Chlorogenic acid (1) & 17.09 & $27.23 \pm 0.17$ & 51.02 & $4.2 \pm 3.20$ \\
\hline Formononetin-7-O- $\beta$-D-glucosyl [1-6] glucoside (2) & 1.04 & $>500$ & 2.32 & $>500$ \\
\hline trans-Ferulic acid (3) & 20.06 & $13.51 \pm 0.04$ & 5.21 & $>500$ \\
\hline Tectoridin (4) & 8.43 & $>500$ & 43.37 & $50.4 \pm 2.17$ \\
\hline Piceatannol (5) & 34.68 & $6.73 \pm 0.04$ & 5.47 & $>500$ \\
\hline Resveratrol (6) & 29.96 & $11.05 \pm 0.04$ & 29.31 & $117.6 \pm 3.12$ \\
\hline Daidzein $(7)$ & 0.48 & $>500$ & 28.14 & $151.9 \pm 2.91$ \\
\hline Genistein (8) & 2.24 & $>500$ & 38.54 & $57.1 \pm 3.23$ \\
\hline Formononetin (9) & 0.69 & $>500$ & 30.11 & $69.2 \pm 2.57$ \\
\hline Trolox $^{\mathrm{d}}$ & - & $16.83 \pm 0.06$ & - & - \\
\hline Quercetin $^{\mathrm{e}}$ & - & - & - & $10.1 \pm 2.18$ \\
\hline
\end{tabular}

${ }^{a}$ Quantitative reduction was defined as the amount of decrease in ABTS-offline HPLC.

${ }^{\mathrm{b}}$ The $\mathrm{IC}_{50}$ value was defined as the concentration of the $50 \%$ inhibition.

${ }^{\mathrm{c}}$ Inhibition was defined as the amount of efficacy in HPLC microfractionation.

${ }^{\mathrm{d}}$ Trolox was used as positive control for ABTS assay.

${ }^{\mathrm{e}} \mathrm{Quercetin}$ was used as positive control for RLAR inhibitory activity measurement.

considered for two-phase solvent systems. First, to assure safety retention of the stationary phase, the settling time of the solvent system should be within $30 \mathrm{~s}$. The second factor is that the partition coefficient $(K)$ of the target compounds has to be within the range $0.5 \leq K \leq 2.5$ for efficient separation. Lastly, the separation factor between the components $(\alpha=$ $K 2 / K 1, K 2>K 1)$ should be greater than $1.5[26,27]$. In this study, the $K$ values of the 5 compounds were determined by HPLC, as described in Materials and Methods. The measured $K$ values of each compound are summarized in Table 2. Based on the criteria for $K$ values, one system was selected with nhexane-ethyl acetate-methanol-water $(2.5: 7.5: 5: 5, \mathrm{v} / \mathrm{v})$ and five compounds (5-9) isolated by its system were evaporated to yield 170.1, 94.6, 8.2, 10.4, and $5.5 \mathrm{mg}$.

The structure activity relationship (SAR) of active compounds was investigated using the antioxidant and RLAR assay. Stilbenes structures, compounds 5 and 6 , showed the highest antioxidant activity, and compound 5 had more antioxidant activity than compound 6 because it has four hydroxyl groups, including a catechol structure in the $\mathrm{B}$ ring [28]. The phenolic compounds showed the second highest antioxidant activity and as compared to compounds 1 and 3 , compound 3 appears to have more high antioxidative efficiency caused by their methoxy group [29]. In SAR of RLAR assay, active compounds were divided into three groups as phenolic acids, stilbenes, and flavonoids, as shown in Figure 3. Compound 1, a phenolic acid, is commonly found in plants and is a known antioxidant, metal chelator, and AR inhibitor in vitro [30]. Compound 3, with a similar structure, showed lower inhibition of AR because it has a methyl group instead of quinic acid. Flavonoid compounds also showed high inhibition of RLAR. Compound 4 exhibited effective activity because of a hydroxyl group and a methoxyl group in ring $\mathrm{A}$, which is associated with $\mathrm{AR}$ inhibitory activity [31]. The activity of compounds 7 and 8 was attributed to the free hydroxyl group at C-7, which is a significant component for the inhibitory efficacy of AR. First, these have the ability to form a hydrogen bond with amino acids Tyr48 and His110 in an enzyme's active site [32]. Furthermore, 2-phenyl substitution was found to be a suitable hydrophobic pocket of the enzyme lined with amino acids Trp111 and Leu300 due to its aromatic fragment and lipophilic nature as well as its specific spatial conformation [33]. Finally, the 40-hydroxyl group seems to play an important role in the ARI activity of these compounds, as it can form a bond to amino acid Thrll3 [34]. Compound 8 has previously been reported to have an inhibitory effect on AR activity and increase GSH levels, which may help to prevent xylose-induced opacity of diabetic lenses [35]. Compound 8 had better inhibition than 7 because it has a hydroxyl group in ring $\mathrm{A}$, as mentioned above. Another flavonoid compound, compound 9, also exhibited inhibitory activity against AR owing to the substitution of a hydroxyl group with a methoxy group at C- $4^{\prime}$ [36]. When we compared compounds 6 and 5, which contain stilbenes, the activity of 6 without the hydroxyl group at C- $3^{\prime}$ was one hundred times higher than that of 5. Compound 6 is already known as an antioxidant and effectively reduces blood sugar in streptozotocin-induced diabetic rats and normalizes renal dysfunction in diabetic rats [37]. Compound 6 increased superoxide dismutase, catalase, glutathione peroxidase, glutathione-S-transferase, and glutathione reductase activities and vitamins $\mathrm{C}$ and $\mathrm{E}$ and reduced glutathione levels, with a significant decline in lipid peroxide, hydroperoxide, and protein carbonyl levels in diabetic kidneys [38].

\section{Conclusion}

The ABTS-HPLC offline radical scavenging analysis method and HPLC microfractionation system are the rapid determination methods of active components in MA. Based on 
the rapid determination methods, HSCCC was successfully applied to separate and purify compounds using hexane-ethyl acetate-methanol-water $(2.5: 7.5: 5: 5, \mathrm{v} / \mathrm{v})$ as the solvent system and four compounds were isolated using the Sephadex LH-20 column chromatography. In addition, the RLAR and ABTS radical scavenging inhibitory activities of MA and its constituents were investigated. MA and its constituents showed high inhibitory activities regarding RLAR and ABTS. Among them, chlorogenic acid and piceatannol were identified as potential antioxidants and RLAR inhibitors. Therefore, our results suggested that HSCCC based on ABTS-HPLC offline analysis method and HPLC microfractionation system are a powerful and fast technique for determining, separating, and purifying active compounds from natural sources and MA can be a potent functional food ingredient as $A R$ and protective of oxidative stress.

\section{Abbreviations}

ABTS: 2,2'-Azino-bis(3-ethylbenzothiazline-6-sulfonic acid) diammonium salt

AR: $\quad$ Aldose reductase

n-BuOH: n-Butanol

$\mathrm{CH}_{2} \mathrm{Cl}_{2}$ : Methylene chloride

DMSO: Dimethyl sulfoxide

EtOAc: Ethyl acetate

n-Hex: $n$-Hexane

$\mathrm{H}_{2} \mathrm{O}: \quad$ Distilled water

HSCCC: High-speed countercurrent chromatography

K: $\quad$ Partition coefficient

MA: $\quad$ Maackia amurensis

NADPH: Nicotinamide adenine dinucleotide phosphate

NADH: Nicotinamide adenine dinucleotide

RLAR: Rat lens aldose reductase

SAR: $\quad$ Structure activity relationship

TEAC: Evaluation of trolox equivalent antioxidant capacity

Trolox: 6-Hydroxy-2,5,7,8-tetrame-thylchroman-2carboxylic acid.

\section{Conflicts of Interest}

The authors have declared no conflicts of interest.

\section{Authors' Contributions}

Set Byeol Kim and Seung Hwan Hwang have contributed equally to this work.

\section{Acknowledgments}

This research was supported by Hallym University Research Fund 2017 (H20170035).

\section{References}

[1] T. H. Kim, J. K. Kim, Y.-H. Kang, J.-Y. Lee, I. J. Kang, and S. S. Lim, "Aldose reductase inhibitory activity of compounds from
Zea mays L.," BioMed Research International, vol. 2013, Article ID 727143, 8 pages, 2013.

[2] H. M. Li, J. K. Kim, J. M. Jang, S. O. Kwon, C. B. Cui, and S. S. Lim, "The inhibitory effect of Prunella vulgaris L. on aldose reductase and protein glycation," BioMed Research International, vol. 2012, Article ID 928159, 7 pages, 2012.

[3] P. Thiraphatthanavong, J. Wattanathorn, S. Muchimapura et al., "Preventive effect of Zea mays L. (purple waxy corn) on experimental diabetic cataract," BioMed Research International, vol. 2014, Article ID 507435, 8 pages, 2014.

[4] W. Ying, "NAD+/NADH and NADP+/NADPH in cellular functions and cell death: regulation and biological consequences," Antioxidants and Redox Signaling, vol. 10, no. 2, pp. 179-206, 2008.

[5] N. Matsuura, T. Aradate, C. Kurosaka et al., "Potent protein glycation inhibition of plantagoside in Plantago major seeds," BioMed Research International, vol. 2014, Article ID 208539, 5 pages, 2014.

[6] S.-R. Yoon and S.-M. Shim, "Inhibitory effect of polyphenols in Houttuynia cordata on advanced glycation end-products (AGEs) by trapping methylglyoxal," LWT-Food Science and Technology, vol. 61, no. 1, pp. 158-163, 2015.

[7] X. Li, J. Li, D. Wang, W. Wang, and Z. Cui, "Chromone and flavonoids from Maackia amurensis," Asian Journal of Traditional Medicines, vol. 4, no. 3, pp. 98-103, 2009.

[8] N. Li, N. Zhang, J.-L. Li, P.-G. Du, H.-S. Lee, and L. Cui, "Inhibition of diacylglycerol acyltransferase by prenylated flavonoids isolated from the stem bark of Maackia amurensis," Journal of Asian Natural Products Research, vol. 17, no. 2, pp. 178-181, 2015.

[9] X. Li, D. Wang, M. Y. Xi, Z.-H. Wang, W.-N. Wang, and Z. Cui, "Cytotoxic prenylated flavonoids from the stem bark of Maackia amurensis," Chemical and Pharmaceutical Bulletin, vol. 57, no. 3, pp. 302-306, 2009.

[10] S. Shi, Y. Ma, Y. Zhang et al., "Systematic separation and purification of 18 antioxidants from Pueraria lobata flower using HSCCC target-guided by DPPH-HPLC experiment," Separation and Purification Technology, vol. 89, no. 22, pp. 225233, 2012.

[11] J. H. Paek, K. H. Shin, Y.-H. Kang, J.-Y. Lee, and S. S. Lim, "Rapid identification of aldose reductase inhibitory compounds from Perilla frutescens," BioMed Research International, vol. 2013, Article ID 679463, 8 pages, 2013.

[12] N. Pellegrini, R. Re, M. Yang, and C. Rice-Evans, "Screening of dietary carotenoids and carotenoid-rich fruit extracts for antioxidant activities applying 2,2 '-azinobis(3-ethylenebenzothiazoline-6- sulfonic acid radical cation decolorization assay," Methods in Enzymology, vol. 299, pp. 379-389, 1998.

[13] A. Gliszczynska-Swiglo, "Antioxidant activity of water soluble vitamins in the TEAC (trolox equivalent antioxidant capacity) and the FRAP (ferric reducing antioxidant power) assays," Food Chemistry, vol. 96, no. 1, pp. 131-136, 2006.

[14] S. Hayman and J. H. Kinoshita, "Isolation and properties of lens aldose reductase," The Journal of Biological Chemistry, vol. 240, pp. 877-882, 1965.

[15] Y. S. Lee, Y.-H. Kang, J.-Y. Jung et al., "Inhibitory constituents of aldose reductase in the fruiting body of Phellinus linteus," Biological and Pharmaceutical Bulletin, vol. 31, no. 4, pp. 765$768,2008$.

[16] U.-H. Jin, J.-Y. Lee, S.-K. Kang et al., "A phenolic compound, 5caffeoylquinic acid (chlorogenic acid), is a new type and strong 
matrix metalloproteinase-9 inhibitor: isolation and identification from methanol extract of Euonymus alatus," Life Sciences, vol. 77, no. 22, pp. 2760-2769, 2005.

[17] H. Youn, S. Lee, J.-H. Cho, and H. Oh, "Insecticidal isoflavon glycoside from Maackia amurensis," Archives of Pharmacal Research, vol. 14, no. 2, pp. 105-108, 1991.

[18] S. E. Sajjadi, Y. Shokoohinia, and N.-S. Moayedi, "Isolation and identification of ferulic acid from aerial parts of Kelussia odoratissima mozaff," Jundishapur Journal of Natural Pharmaceutical Products, vol. 7, no. 4, pp. 159-162, 2012.

[19] T. Yoshioka, T. Inokuchi, S. Fujioka, and Y. Kimura, "Phenolic compounds and flavonoids as plant growth regulators from fruit and leaf of Vitex rotundifolia," Zeitschrift für Naturforschung C, vol. 59, no. 7-8, pp. 509-514, 2004.

[20] Y. Xiong, Y. Yang, J. Yang et al., “Tectoridin, an isoflavone glycoside from the flower of Pueraria lobata, prevents acute ethanol-induced liver steatosis in mice," Toxicology, vol. 276, no. 1, pp. 64-72, 2010.

[21] T. Han, G. Cheng, Y. Liu, H. Yang, Y.-T. Hu, and W. Huang, "In vitro evaluation of tectoridin, tectorigenin and tectorigenin sodium sulfonate on antioxidant properties," Food and Chemical Toxicology, vol. 50, no. 2, pp. 409-414, 2012.

[22] H.-Y. Sun, C.-F. Xiao, Y.-C. Cai et al., "Efficient synthesis of natural polyphenolic stilbenes: resveratrol, piceatannol and oxyresveratrol," Chemical and Pharmaceutical Bulletin, vol. 58, no. 11, pp. 1492-1496, 2010.

[23] M. S. Kale and K. S. Laddha, "Isolation, characterization and quantification of isoflavone in Momordica dioica roxb. ex wild (cucurbitaceae) fruits," International Journal of Applied Research in Natural Products, vol. 5, no. 4, pp. 28-36, 2012.

[24] D. Durango, W. Quiñones, F. Torres, Y. Rosero, J. Gil, and F. Echeverri, "Phytoalexin accumulation in Colombian bean varieties and aminosugars as elicitors," Molecules, vol. 7, no. 11, pp. 817-832, 2002.

[25] S. Sato, J. Takeo, C. Aoyama, and H. Kawahara, "Na+-Glucose cotransporter (SGLT) inhibitory flavonoids from the roots of Sophora flavescens," Bioorganic and Medicinal Chemistry, vol. 15, no. 10, pp. 3445-3449, 2007.

[26] Y. Ito, "Golden rules and pitfalls in selecting optimum conditions for high-speed counter-current chromatography," Journal of Chromatography A, vol. 1065, no. 2, pp. 145-168, 2005.

[27] B. Li, W. Du, D. Qian, and Q. Du, "Combination of highspeed countercurrent chromatography and reversed phase $\mathrm{C} 18$ chromatography for large-scale isolation of cyanidin-3-O- $\beta$-dglucoside from black rice bran extract," Industrial Crops and Products, vol. 37, no. 1, pp. 88-92, 2012.

[28] P. W. Teguo, B. Fauconneau, G. Deffieux, F. Huguet, J. Vercauteren, and J.-M. Mérillon, "Isolation, identifieation, and antioxidant activity of three stilbene glucosides newly extracted from Vitis vinifera cell cultures," Journal of Natural Products, vol. 61, no. 5, pp. 655-657, 1998.

[29] J. H. Chen and C.-T. Ho, "Antioxidant activities of caffeic acid and its related hydroxycinnamic acid compounds," Journal of Agricultural and Food Chemistry, vol. 45, no. 7, pp. 2374-2378, 1997.

[30] C.-S. Kim, J. Kim, Y. M. Lee, E. Sohn, K. Jo, and J. S. Kim, "Inhibitory effects of chlorogenic acid on aldose reductase activity in vitro and cataractogenesis in galactose-fed rats," Archives of Pharmacal Research, vol. 34, no. 5, pp. 847-852, 2011.

[31] C. Veeresham, A. Rama Rao, and K. Asres, "Aldose reductase inhibitors of plant origin," Phytotherapy Research, vol. 28, no. 3, pp. 317-333, 2014.
[32] L. Costantino, G. Rastelli, G. Cignarella, P. Vianello, and D. Barlocco, "New aldose reductase inhibitors as potential agents for the prevention of long-term diabetic complications," Expert Opinion on Therapeutic Patents, vol. 7, no. 8, pp. 843-858, 1997.

[33] A. Urzhumtsev, F. Tête-Favier, A. Mitschler et al., "A 'specificity' pocket inferred from the crystal structures of the complexes of aldose reductase with the pharmaceutically important inhibitors tolrestat and sorbinil," Structure, vol. 5, no. 5, pp. 601612, 1997.

[34] G. Rastelli, L. Antolini, S. Benvenuti, and L. Costantino, "Structural bases for the inhibition of aldose reductase by phenolic compounds," Bioorganic and Medicinal Chemistry, vol. 8, no. 5, pp. 1151-1158, 2000.

[35] Y. S. Kim, N. H. Kim, D. H. Jung et al., "Genistein inhibits aldose reductase activity and high glucose-induced TGF- $\beta 2$ expression in human lens epithelial cells," European Journal of Pharmacology, vol. 594, no. 1-3, pp. 18-25, 2008.

[36] C.-H. Park, S. L. Soon, and D.-U. Lee, "Structure-activity relationships of components from the roots of Pueraria thunbergiana having aldose reductase inhibitory and antioxidative activity," Bulletin of the Korean Chemical Society, vol. 28, no. 3, pp. 493-495, 2007.

[37] H.-C. Su, L.-M. Hung, and J.-K. Chen, "Resveratrol, a red wine antioxidant, possesses an insulin-like effect in streptozotocininduced diabetic rats," American Journal of Physiology-Endocrinology and Metabolism, vol. 290, no. 6, pp. E1339-E1346, 2006.

[38] P. Palsamy and S. Subramanian, "Resveratrol protects diabetic kidney by attenuating hyperglycemia-mediated oxidative stress and renal inflammatory cytokines via Nrf2-Keap1 signaling," Biochimica et Biophysica Acta-Molecular Basis of Disease, vol. 1882, no. 7, pp. 719-731, 2011. 

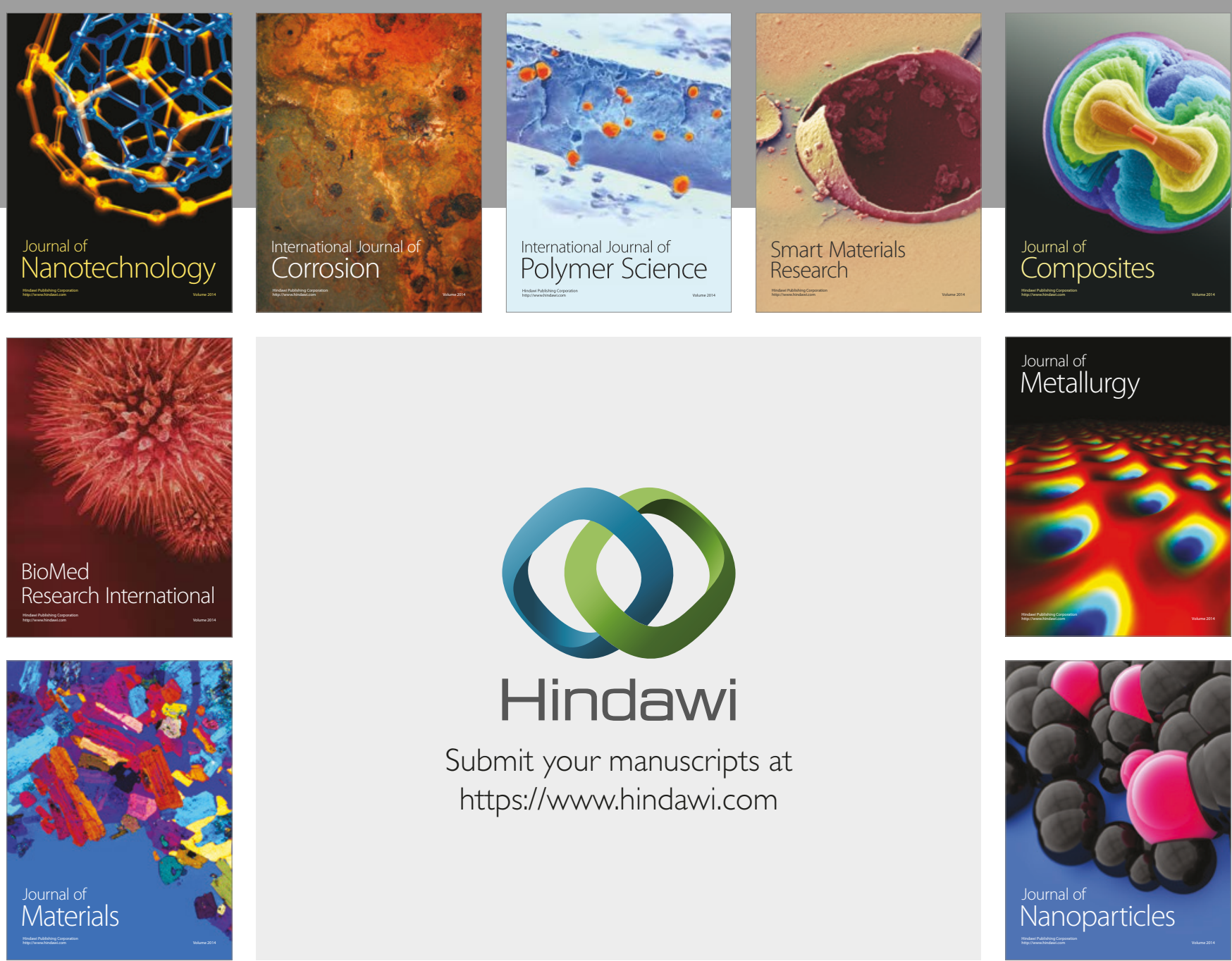

\section{Hindawi}

Submit your manuscripts at

https://www.hindawi.com
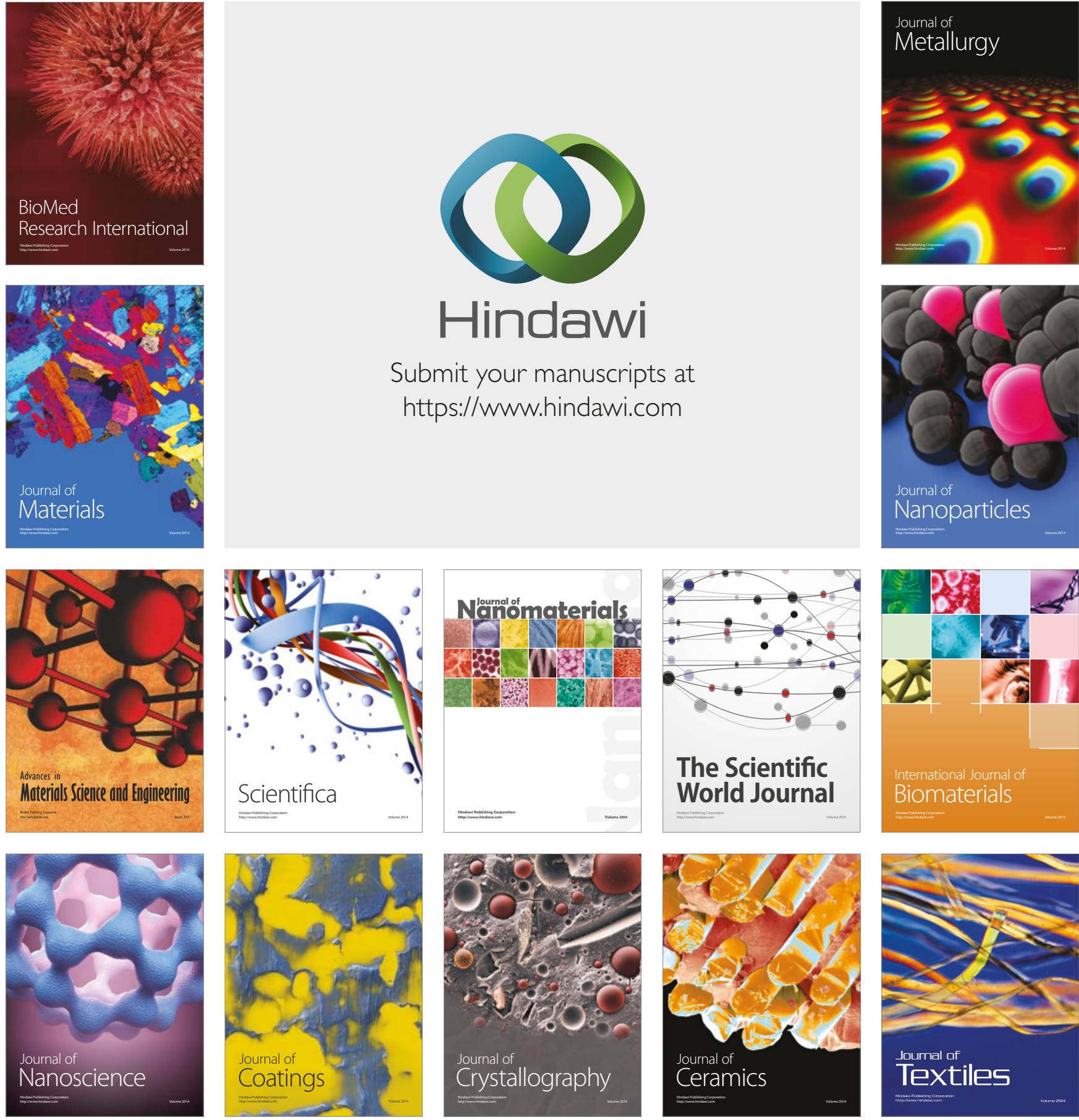

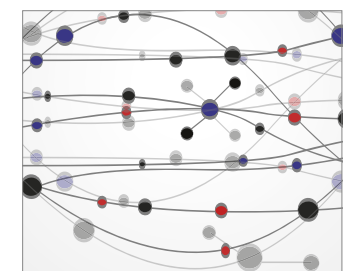

The Scientific World Journal
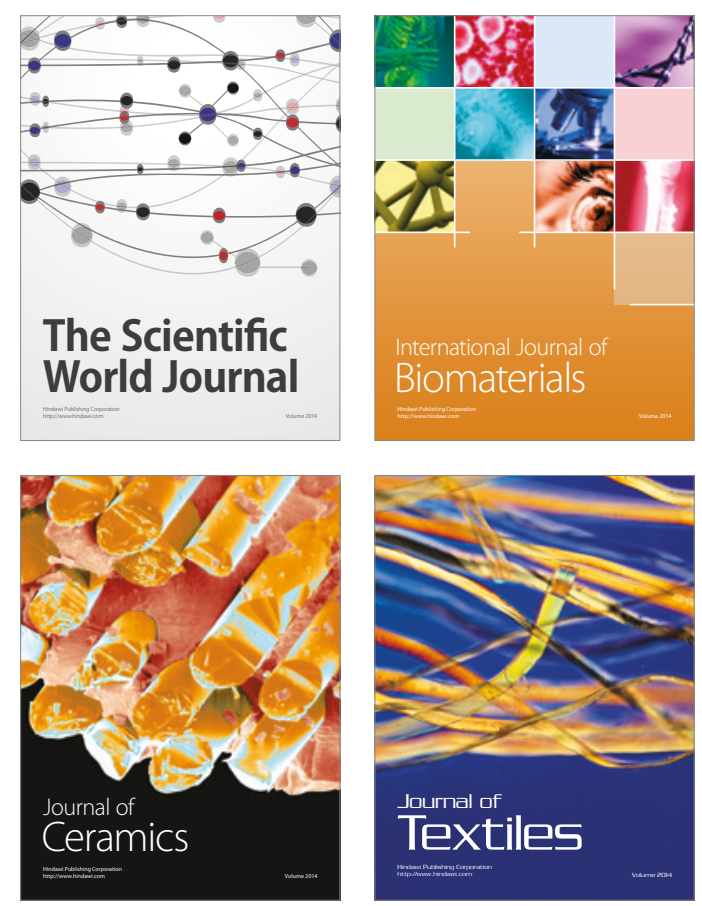